\title{
O DIREITO À BUSCA DA FELICIDADE: FILOSOFIA, BIOLOGIA E CULTURA
}

\author{
THE RIGHT TO THE PURSUIT OF HAPPINESS: PHILOSOPHY, BIOLOGY AND CULTURE \\ EL DERECHO A LA BÚSQUEDA DE LA FELICIDAD: FILOSOFÍA, BIOLOGÍA Y CULTURA
}

Joyceane Bezerra de Menezes ${ }^{1}$

Rogério Parentoni Martins²

A esperança brota eterna do peito do homem Ele nunca é, mas sempre espera ser feliz A alma, inquieta, confinada em seu lar Descansa e discorre sobre uma vida futura. Alexander Pope (1733). Ensaio sobre o homem. In: Semmer, M. Por que as pessoas acreditam em coisas estranhas. Trad. Luis Reyes Gil. JSN Editora, 2011.

Ai de ti e de todos que levam a vida a querer inventar a máquina de fazer felicidade. Fernando Pessoa (1913-1915). Poemas inconjuros. Obra poética. Volume único. Rio de Janeiro: Editora Nova Aguilar S.A., p.231.

\section{RESUMO}

A partir de contributos da filosofia, da biologia, da antropologia e da economia, este artigo traz uma reflexão sobre o direito à busca da felicidade. Embora haja uma multiplicidade de significados para o conceito felicidade, muitos dos quais inconciliáveis, ora tratando-a como virtude, ora como sensação de prazer, ora como promessa de recompensa futura, observou-se certa objetivação do conceito, no mundo ocidental, a partir do utilitarismo de Jeremy Bentham e da inclusão, por meio de Thomas Jefferson, do direito à busca da felicidade no texto da declaração da independência americana. Além das discussões sobre seus possíveis significados, a origem da felicidade também foi pauta de muitos estudos: a biologia apresentou uma explicação amparada no critério da predisposição genética, enquanto outros estudos enfocaram a importância da cultura para a conquista da felicidade. Independentemente das propensões criadas a partir de cada uma dessas disciplinas, a felicidade, na história recente, é utilizada como importante indicador para aferir o desenvolvimento econômico de uma nação, sendo qualificada pela Organização das Nações Unidas, em resolução específica, como um objetivo humano fundamental que deve ser contemplado nas políticas públicas dos Estados. Em face do interesse que o tema desponta, é de se questionar seus fundamentos na área do Direito. Seria a felicidade uma espécie de necessidade humana apta a fundamentar um novo direito? Seria algo mais subjetivo, de matiz prospectiva, que motiva o homem a realizar, criar e interagir com os demais? Nesse plano, dada a abstração que a felicidade alcançaria, sua disciplina jurídica estaria jungida à garantia da busca pela felicidade e, portanto, capitulada no âmbito da autonomia, da liberdade. É certo que, para permitir esse projetar-se, muitas condições materiais são imprescindíveis, razão pela qual também são objeto de garantia jurídica. No contexto atual, essas condições são análogas àquelas aplicadas pela economia para apurar a capacidade que tem um Estado de promover a felicidade, quais sejam: a garantia dos acessos à educação, à saúde, ao transporte e ao trabalho, um meio ambiente ecologicamente equilibrado, dentre outros. O estudo segue uma metodologia qualitativa, a partir de uma pesquisa de cunho bibliográfico e documental.

1 Doutora em Direito pela Universidade Federal de Pernambuco. Mestre em Direito pela Universidade Federal do Ceará. Professora adjunto, nível 06 da Universidade de Fortaleza - Unifor, responsável pela disciplina de Direitos da personalidade no Programa de Pós-Graduação Stricto Sensu (Mestrado e Doutorado); Professora adjunto 04 da Universidade Federal do Ceará, onde ministra a disciplina de Direito de Família. Coordenadora do Grupo de Pesquisa Direito Constitucional nas Relações Privadas - CNPQ. <joyceane@unifor.br.

2 Doutorado em Ecologia pela Universidade Estadual de Campinas (1991). Pós-doutorado no Departamento de Zoologia da Universidade da Florida, Gainesville. Professor-visitante no Departamento de Biologia da Universidade Federal do Ceará, Fortaleza. wasp@icb.ufmg.br. 
PALAVRAS-CHAVE: Direito à busca da felicidade. Biologia. Cultura. Filosofia.

\begin{abstract}
Although there is a multiplicity of meanings for the term happiness, attempts towards an objective view of this concept have been made in the Western world. For instance, in Jeremy Bentham 's utilitarianism and in Thomas Jefferson's inclusion of the right to the pursuit of happiness in the American Declaration of Independence. In addition to discussions about its possible meanings, the source of happiness has also been the agenda of many studies: biology presented an explanation supported by the criterion of genetic predisposition, while other studies, especially anthropological, focused on the importance of culture. Regardless of the biases created from each of these disciplines, in recent history, happiness has been used as an important indicator of economic development, being qualified by the United Nations, in a particular resolution, as a fundamental human goal that must be considered by state public policies. In the face of the great interest that the subject arouses, it is legitimate to question its foundations in the field of law. Is happiness a kind of human need that could support a "new" Right? Or is it be something more subjective, of an exploratory nature, which motivates man to perform, create and interact with others? In this context, given the level of abstraction that the concept of happiness can reach; its legal discipline would be encompassed by disciplines that focus on the guarantees of the pursuit of happiness, and would therefore would be considered under questions of autonomy and liberty. Admittedly, to allow this projection, many basic human needs are indispensable, hence also subject to legal guarantees. In the current context, these conditions are analogous to those used by economists to measure the state capacity to promote happiness, namely: the guarantee of access to education, health, transport, labor, and an ecologically-balanced environment, among others. The study follows a qualitative methodology, based on a bibliographic survey.
\end{abstract}

KEYWORDS: The right to pursue happiness. Biology. Culture. Philosophy.

\title{
RESUMEN
}

A partir de contribuciones de la filosofía, de la biología, de la antropología y de la economía, este artículo presenta una reflexión sobre el derecho a la búsqueda de la felicidad. Aunque haya una multiplicidad de significados para el concepto de felicidad, muchos de los cuales inconciliables, ya tratándola como virtud, ya como sensación de placer, ya como promesa de recompensa futura, se observó cierta objetivación del concepto en el mundo occidental a partir del utilitarismo de Jeremy Bentham y de la inclusión, por medio de Thomas Jefferson, del derecho a la búsqueda de la felicidad en el texto de la Declaración de la Independencia Americana. Además de las discusiones sobre sus posibles significados, el origen de la felicidad también fue pauta de muchos estudios: la biología presentó una explicación amparada en el criterio de la predisposición genética, mientras que otros estudios enfocaron la importancia de la cultura para la conquista de la felicidad. Independientemente de las propensiones creadas a partir de cada una de esas disciplinas, la felicidad, en la historia reciente, es utilizada como importante indicador para evaluar el desarrollo económico de una nación, siendo calificada por la Organización de las Naciones Unidas, en resolución específica, como un objetivo humano fundamental que debe ser contemplado en las políticas públicas de los Estados. Frente al interés que el tema despierta, es preciso cuestionar sus fundamentos en el área del Derecho. ¿Sería la felicidad una especie de necesidad humana apta a fundamentar un nuevo derecho? ¿Sería algo más subjetivo, de matiz prospectivo, que motiva al hombre a realizar, crear e interactuar con los demás? En ese plano, dada la abstracción que la felicidad alcanzaría, su disciplina jurídica estaría sujeta a la garantía de la búsqueda de la felicidad y, por lo tanto, capitulada en el ámbito de la autonomía, de la libertad. Es cierto que para permitir ese proyectarse son imprescindibles muchas condiciones materiales, razón por la cual también son objeto de garantía jurídica. En el contexto actual esas condiciones son análogas a aquellas aplicadas por la economía para averiguar la capacidad que 
tiene un Estado de promover la felicidad, a saber: la garantía de los accesos a la educación, a la salud, al transporte y al trabajo, un medio ambiente ecológicamente equilibrado, entre otros. El estudio sigue una metodología cualitativa a partir de una investigación de cuño bibliográfico y documental.

PALABRAS CLAVE: Derecho a la búsqueda de la felicidad. Biología. Cultura. Filosofía.

\section{INTRODUÇÃO}

O interesse em se compreender o significado do conceito de felicidade atravessa séculos de história. Foram os filósofos, sem dúvidas, que mais se aventuraram nesse propósito. Porém, examinando-se as diversas épocas e as concepções filosóficas, verifica-se um predomínio de duas compreensões sobre felicidade: ora associada à sensação a ser alcançada por meio do estímulo dos sentidos, expressa por meio de satisfações das necessidades imediatas, ora como um estado de espírito de paz e tranquilidade duradouras. Nota-se também que os contextos nos quais tais concepções vigeram se caracterizaram por uma busca da felicidade a partir de referenciais internos, como as próprias emoções individuais, e de referenciais externos, a exemplo da influência dos deuses sobre os destinos humanos.

Todavia, considerando o indivíduo como um ser natural, resultado de um processo evolutivo, é de se perguntar se a felicidade não estaria ligada a características biológicas comportamentais, como também é de se avaliar a influência da cultura no plano comportamental em paralelo às variáveis biológicas. Há estudos que pretendem, inclusive, mensurar quais desses elementos, biológicos ou culturais, mais influenciaram o comportamento humano. A par da discussão sobre o impacto desses fatores na concretização ou não da felicidade, a esperança de alcançar a felicidade motivou comportamentos que influenciaram as relações de trabalho, as perspectivas religiosas e a própria estruturação da família.

A discussão sobre felicidade individual recebe mais atenção apenas na história recente a partir da emergência da ideia de self. A compreensão do indivíduo como sendo o autor de sua própria história fundamentou as pesquisas e as concepções da psicanálise e da psicologia e fortaleceu as discussões sobre sua autonomia. E, nessa linha, a felicidade é abordada como um alvo a ser perseguido pelo sujeito que segue construindo a sua própria história, a partir de sua autodeterminação, atributo de sua autonomia.

São tantos os estudos sobre a matéria nos dias atuais que foram propostos indicadores econômicos que visam mensurar o nível de felicidade de uma nação, a exemplo do FIB - Felicidade Interna Bruta.

No plano jurídico, a matéria alcança nível constitucional. Países como os Estados Unidos e Portugal preveem, em suas respectivas constituições, o direito à busca da felicidade. No Brasil, a jurisprudência refere-se ao postulado direito à busca da felicidade enquanto tramita um Projeto de Emenda Constitucional, visando à sua inclusão no artigo sexto, ao lado de outros direitos sociais. Considerando as diferentes perspectivas sobre as quais a felicidade é apreciada, ora designada pela filosofia, ora pela psicanálise, ora pela economia, é de se perguntar pela dimensão jurídica da felicidade. O que é felicidade? Qual seria o objeto do direito à busca da felicidade? Seria a felicidade uma necessidade irrecusável ao desenvolvimento do homem?

O propósito desse estudo é analisar como o Direito pode intervir no deslinde desse "projeto felicidade", especialmente quando o foco é a felicidade individual. A discussão parte de uma análise geral do conceito felicidade a partir da filosofia, da biologia, da antropologia e da economia para, em seguida, apresentar os limites e as possibilidades de tratamento do tema no âmbito do Direito.

\section{O SIGNIFICADO DE FELICIDADE E A SUA EVENTUAL INCLUSÃO COMO OBJETO DE DIREITO}

Embora filósofos, historiadores, psicanalistas, psicólogos, biólogos, economistas, teólogos, poetas e artistas, em todos os tempos e culturas, já refletissem sobre o que é felicidade, não há consenso 
sobre a sua origem e significados. Por isso, o tema continua aberto e ainda atrai a atenção. Apesar de não haver uma definição objetiva e consensual sobre felicidade, há expectativas de que seja algo que o homem, em sua subjetividade, deva experimentar a fim de suportar o enorme peso de existir ${ }^{3}$.

Viver feliz seria uma meta para o futuro, portanto, um projeto a se realizar. Essa concepção é vigente em diversas religiões ${ }^{4}$, sob os pretextos de que sofrimentos, privações e sacrifícios são oportunidades para que o espírito humano se aperfeiçoe e logre, após a morte, o gozo eterno. Exemplo radical é o dos jovens mulçumanos - homens-bomba suicidas, geralmente recrutados entre pessoas miseráveis, ignorantes e crédulas, que vislumbram uma vida melhor no paraíso em companhia de Alá. Acreditam que lá serão recompensados, por sua abnegação e sacrifício, por meio do direito de usufruir a companhia e os favores de virgens. Na compreensão de Santo Agostinho e de Santo Tomás de Aquino, a felicidade aqui na terra é imperfeitamente realizável, pois o gozo da felicidade é a marca do outro Reino ${ }^{5}$.

Essa falta de consenso a respeito do conceito de felicidade poderá, pelo menos em parte, ser atribuída à interpretação subjetiva sobre um amplo leque de possibilidades de sentir-se feliz. Alguns afirmam sentir felicidade após vivenciar episódios que Ihes trazem efêmeras sensações de prazer, guardando a esperança de que se repitam. Tais episódios podem resultar de causas biológicas e culturais. Por exemplo, a simples ingestão de água por alguém sedento poderá evocar uma sensação instantânea de prazer; um cientista que proponha melhor explicação para um fenômeno poderá também sentir-se feliz. Um convertido poderá sentir-se em júbilo por crer que Deus exerceu uma influência positiva sobre determinadas circunstâncias de sua vida. Contrariamente, para alguns psicólogos e filósofos, essa concepção não caracterizaria, de fato, felicidade. Para eles, a felicidade seria caracterizada por meio de um estado mais duradouro de satisfação e bem-estar, a partir do exercício permanente e coerente de virtudes, tais como honestidade, compaixão e reciprocidade . $^{6}$.

A concepção de felicidade como satisfação efêmera é mais recorrente na história7 e parece prevalecer na chamada sociedade pós-moderna. Neste caso, ser feliz implica a satisfação de desejos de consumo, na maioria das vezes, criados pela própria mídia e técnicas usuais de marketing. 0 resultado da investida midiática, aparentemente dirigida a um indivíduo específico, amplia-se quando atinge diversos sujeitos e causa uma espécie de homogeneização dos desejos por meio de promessas de venda da felicidade. Porém, se o estado de felicidade resultasse apenas da aquisição dos bens, objetos de desejo, o único problema existencial da humanidade seria o de ganhar dinheiro para que tais anseios fossem satisfeitos. No entanto, há estudos indicando o contrário, ou seja, que acima de certo patamar, ganhar mais dinheiro não incrementa o nível de felicidade ${ }^{8}$.

Se o objetivo do texto é tratar da felicidade individual, antes de se avançar, é importante observar quando surgiu a ideia de self.

$\mathrm{Na}$ antiguidade, a identidade passa por três fases distintas ${ }^{9}$ : a primeira delas é a fase homérica ou da sociedade heroica, na qual o ser humano era compreendido apenas em sua inserção social inevitável. O ser era uma circunstância, e não um agir em face das circunstâncias. Atrelado que era à ideia da polis, ao mundo social, o eu homérico não conheceu a ideia de felicidade individual, dissonante do projeto coletivo, público. $^{1}$

A segunda fase, de orientação aristotélica, informa uma identidade em busca do bem, por meio do apego às virtudes. Embora inserta numa ordem moral e social, o homem tem identidade distinta dos papéis sociais que assume. Nesta fase, há um eu de necessidades, de virtudes e de papéis,

3 FREUD, Sigmund. O mal-estar na civilização. Sigmund Freud, Obras completas, vol. 18, Trad. Paulo César de Souza. São Paulo: Editora Companhia das Letras, 2010.

4 MCMAHON, Darrin. Felicidade: uma história. São Paulo: Editora Globo, 2006.

5 FRANCO FILHO, Odilon de Melo. A civilização do mal estar pela não-felicidade. Revista brasileira de psicanálise Vol. 43, n², 183-192, 2009. p.3.

6 FRANKLIN, Samuel. The psychology of happiness. Cambridge University Press, New York, 2010; HEIDT, Jonathan. The happiness hypothesis - finding modern truth in Ancient Wisdom. Boston: Basic Books, 2005.

7 MCMAHON, Darrin. Felicidade: uma história. São Paulo: Editora Globo, 2006.

8 GRAHAM, Carol. Happiness around the world: the paradox of happy peasants and miserable millionaires. New York: Oxford University Press, 2009.

9 GUSTIN, Miracy. Das necessidades humanas aos direitos: ensaio de sociologia e filosofia do direito. Belo Horizonte: Del Rey, 2009. p. 29. 
que se destaca do todo, apesar da importância de se manter em completa harmonia com a ordem natural e com o cosmos ${ }^{10}$. Pelos bons hábitos oriundos da educação zelosa, o homem disporia, com maior facilidade, dos instrumentos necessários para persecução da felicidade. Como um fim último, a felicidade seria procurada por si mesma e nunca em vista de outros interesses. ${ }^{2}$

Assim, a felicidade seria a busca do bem universal que não é, em si, igual para todas as coisas, mas é universal no sentido de configurar aquilo que motiva todas as coisas. Na medicina, o bem seria a saúde; na estratégia, a vitória; na arquitetura, uma casa; em qualquer outra esfera, algo diferente. Mas correspondente à finalidade para a qual cada ação e cada propósito se dirigem.

E sendo a função do homem, uma atividade da alma, o exercício da vida racional, a função de um bom homem seria uma boa e nobre realização de sua vida racional. Realizar as ações de acordo com a excelência que delas se espera é a máxima prática da virtude e, portanto, o caminho da felicidade (1984, p.56). Mas, para alcançar essa virtude, Aristóteles destacava a importância de certos bens exteriores como a beleza, a riqueza e o berço, sem os quais a realização de atos nobres em busca de uma vida feliz se tornaria impossível ou, pelo menos, muito mais difícil. ${ }^{3}$ Talvez por isso, aqui, a ideia de felicidade se confunda com a presença de fortuna.

A terceira, e última fase do mundo antigo, traz a compreensão da identidade a partir das concepções epicuristas, quando a ação humana se liberta do determinismo e da imposição das coisas e das contingências para se justificar na busca pelo prazer (hedone). Os epicuristas cultivavam a ética de que o bem moral estaria no prazer, chave da felicidade, objetivo supremo de toda ação. Ressaltando-se que, aqui, a ideia de bem está dissociada de qualquer ordem de natureza ideal ou real e dos constrangimentos da esfera do necessário, pois, para Epicuro, a natureza já teria inscrito o desejo de prazer em todos nós. Nada obstante, compreendia ele o prazer como aquilo que era saudável, caracterizado pela tranquilidade e não pela intensidade ${ }^{11}$. Em sua concepção, o bem coincide com a faculdade de desejar. Portanto, a felicidade seria a possibilidade de escolher aquilo que se define como o bem e atraí-lo para si, bem como de afastar de si aquilo que se entende como o mal.

Já na visão dos estoicos há uma contraposição ao entendimento de felicidade por meio do prazer. Estes entendiam a felicidade como o resultado de uma vida virtuosa, na qual os desejos são adaptados à ordem do mundo, como um complexo harmonioso e bom, criado pela autoridade divina ${ }^{12}$. A dimensão da identidade nos estoicos perde a importância, pois as pessoas são vistas como engrenagens na composição do todo. Prega-se uma resignação diante dos acontecimentos bons e maus, que passam a ser aceitos como fatos inexoráveis.

Observa-se que, na idade média, o interesse sobre a individualidade era quase totalmente ausente, reaparecendo, com mais intensidade, a partir do romantismo que se iniciou na Europa nas últimas décadas do século XVIII ${ }^{13}$. Apesar de serem antigas as ideias sobre individualidade, interesse individual e potencial de desenvolvimento humano, suas abordagens são na realidade relativamente novas e pouco compreendidas ${ }^{14}$.

Quando o sociólogo Hall ${ }^{15}$ discute a transformação dos significados de identidade na história mais recente, ele apresenta três concepções de identidade: a primeira, correspondente ao sujeito do iluminismo; a segunda, qualificada como o sujeito sociológico e, por fim, a que se vislumbra no sujeito pós-moderno. A identidade do sujeito do iluminismo revela uma perspectiva essencialista, baseada na crença de que, do nascimento à morte, o indivíduo apresenta uma essência individual centrada e unificada, firmada nos pilares da razão, da consciência e da ação. Nesse sentido, talvez fosse possível falar em felicidade como um bem individual, aplicável a toda as fases da existência ou mesmo como um bem coletivo e uniforme destinado igualmente a todos.

10 GUSTIN, Miracy. Das necessidades humanas aos direitos: ensaio de sociologia e filosofia do direito. Belo Horizonte: Del Rey, 2009. p. 31.

$11 \mathrm{SCHOCH}$, Richard. A história da (in)felicidade. Três mil anos de busca por uma vida melhor. Tradução: Elena Gaidano. Rio de Janeiro: Best Seller, 2011. p. 16-17.

12 MINOIS, Georges. A idade de outro. História da busca da felicidade. São Paulo: Editora UNESP, 2011. p. 61.

13 FRANKLIN, Samuel. The psychology of happiness. Cambridge University Press, New York, 2010.

14 FRANKLIN, Samuel. The psychology of happiness. Cambridge University Press, New York, 2010.

15 HALL, Stuart. A identidade cultural na pós-modernidade. Rio de Janeiro: DP\&A Editora, 2011. 
A identidade do sujeito sociológico nasce com a complexidade do mundo moderno e a consciência de que o seu núcleo interior não é autônomo, mas formado por meio de relações sociais. A identidade constituída por meio dessas relações facilitaria a estabilização emocional do sujeito com o mundo exterior. Por meio dessa via, a compreensão de felicidade já demandará a vida de relações, podendo sofrer alterações pelas interações do homem em seu contexto sociocultural.

Na pós-modernidade, a ideia de identidade unificada e estável se fragmenta pela possibilidade de assunção de múltiplas identidades, por vezes, até mesmo contraditórias ${ }^{16}$. 0 caráter essencialista se desfaz pela concepção de uma identidade formada e transformada continuamente ${ }^{17}$. Caberia perguntar: qual seria a influência desses desfazer-se e reconstruir-se sobre o grau de felicidade de um indivíduo? Para aqueles que acreditam em um mal-estar na civilização, essa multifacetada identidade implicaria a perda de vínculos e ampliaria os riscos de sofrimento psíquico. Portanto, a identidade do sujeito pós-moderno já seria um facilitador para o sofrimento, um passo à infelicidade. ${ }^{5}$

A despeito da possível abordagem da felicidade como um projeto da coletividade, enfoca-se a ideia de felicidade individual. Nesse aspecto, é de se cogitar, como propõe o presente texto sobre as possíveis influências da biologia e da cultura sobre o comportamento individual. Haveria uma propensão natural a ser feliz, a partir de atributos genéticos ou, do contrário, a concepção de felicidade seria apenas uma construção cultural? Pode-se afirmar, como uma terceira opção, a de que fatores biológicos e culturais se somariam para a facilitação da conquista do estado de felicidade? Ou, por fim, este estado seria inalcançável? Em que medida poderia conciliar felicidade à ideia de necessidade humana? Poderia o direito se imiscuir nesta seara e assegurar um direito de ser feliz ou seria mais seguro garantir o direito à busca da felicidade?

\section{FELICIDADE: UM IMPULSO NATURAL OU UMA CONSTRUÇÃO CULTURAL?}

Caso se considere que a busca pela felicidade seja um impulso natural, surgirá um obstáculo imposto pela dificuldade em se definir "natural" como propensão. Um dos significados mais óbvios sobre o que é natural corresponde à característica daquilo que provém da natureza, sem interveniência humana. Mas, o ser humano, pelas suas origens biológicas evolutivas, não seria também natural? Esse foi um problema posto pela biologia evolutiva comparativa: o homem compartilha características biológicas, inclusive comportamentais, com os demais mamíferos, classe com a qual é mais biologicamente afim, como, por exemplo, a presença de glândulas mamárias e o ato instintivo de sucção em recém-nascidos. Considerando-se que esses atributos evoluíram por meio da seleção natural, pode-se deduzir que o status da condição "natural" humana seria o mesmo de quaisquer organismos e que, também, o ser humano teria um parentesco remoto com criaturas desprovidas de cultura, como o são bactérias, por exemplo. Lembre-se, porém, que é exatamente a cultura que se evoca para negar ao homem essa condição "natural" e diferenciá-lo dos demais organismos. Apesar de se compartilhar atributos com espécies a nós "inferiores", a cultura supostamente libertaria da influência desse parentesco. Entretanto, e se a própria capacidade de desenvolver cultura puder ser considerada um atributo "natural"? Essa indagação remete a situações conflituosas. Apesar de se haver inventado a cultura ${ }^{18}$ que, supostamente, nos libertou da condição animal "inferior", não se está imune às "incômodas" evidências que reafirmam a nossa condição "natural". Seria talvez essa ambiguidade, manifesta de forma inconsciente, que dificultaria a existência de uma definição objetiva e consensual sobre felicidade?

Sempre houve e haverá conflitos sobre o entendimento do que seria natural. Em especial se se considerar reflexões que partem de diferentes campos científicos, a exemplo das Ciências Sociais e da Biologia. A controvérsia, presente na década de 70, devido à publicação do livro Sociobiology - Nova Síntese ${ }^{19}$, foi um evento típico desse tipo de conflito.

Edward O. Wilson, biólogo estudioso da evolução das sociedades das formigas, tentou projetar para sociedades humanas certas características comportamentais que seriam "naturais" ou, melhor, geneticamente determinadas. Sob essa perspectiva e por ser "naturais", compartilham-se com outras espécies sociais certos comportamentos evoluídos por meio da seleção natural.

$16 \mathrm{HALL}$, Stuart. A identidade cultural na pós-modernidade. Rio de Janeiro: DP\&A Editora, 2011. p. 12.

17 HALL, Stuart. A identidade cultural na pós-modernidade. Rio de Janeiro: DP\&A Editora, 2011.

18 WAGNER, Roy. A invenção da cultura. São Paulo: Cosacnaify, 2010.

19 WILSON, Edward. Sociobiology. Cambridge: Harvard University Press, 1975. 
O impacto que essa proposta de determinismo genético provocou foi tremendo, em especial sobre certos antropólogos que a rechaçaram com veemência ${ }^{20}$. Estes atribuíam à cultura uma influência importante sobre o aprendizado, origem e manifestação de comportamentos sociais. Muito embora a concepção de Wilson influenciasse o desenvolvimento de várias disciplinas, sua concepção "naturalista" nunca foi totalmente convincente, até mesmo entre alguns biólogos ${ }^{21}$.

Por outro lado, a capacidade de desenvolver culturas é considerada até mesmo por antropólogos uma característica adaptativa, ou seja, uma resposta à influência que o meio ambiente exerce sobre os indivíduos ${ }^{22}$. Mas, uma vez estabelecida, uma cultura influencia de forma autônoma comportamentos individuais. Em parte, isso decorre da capacidade humana em "escrever" sua própria história, independentemente do percurso evolutivo que levou a seu surgimento na Terra.

Se essa concepção "naturalista" não alcança consenso nem entre biólogos, quiçá entre psicólogos evolucionistas, como é o caso de Steven Pinker.

Pinker ${ }^{23}$, em revisão recente dos estudos que avaliam as influências da cultura e da biologia (nature $\mathrm{x}$ nurture) sobre o comportamento social humano, mostrou a possibilidade de o grupo social influenciar fortemente a formação da personalidade do indivíduo adulto e sua expectativa de ser feliz. Essas evidências podem indicar que a influência genética sobre o comportamento individual, não obstante importante, pode ser minimizada frente à força majoritária das interações sociais não consanguíneas, como muitos "culturalistas" acreditam. Porém, na avaliação de Pinker ${ }^{24}$, isso não é tão simples assim. Há evidências de que filhos gerados em uma mesma família, incluindo gêmeos idênticos, venham a exibir comportamentos sociais diversos, inclusive percepção diversa do que seja felicidade. Mas também há um acúmulo de evidências a favor da importância da constituição genética na determinação da felicidade.

Um estudo realizado sobre gêmeos idênticos e fraternos norte-americanos, que foram criados juntos ou separados, ainda que vivendo nos EUA, mostrou que apenas os idênticos exibiam níveis semelhantes de felicidade, mesmo quando criados separadamente ${ }^{25}$. $O$ estudo evidencia uma considerável influência da genética sobre o estado individual de felicidade, especialmente se cotejado a outras evidências nas quais as diferenças interindividuais (e.g. renda, educação, ocupação, gênero, idade, religiosidade e outras características demográficas) explicariam apenas pequena fração da variação nos níveis de felicidade. Nada obstante, tenha a influência da genética se mostrado preponderante na determinação dos níveis de felicidade, como demonstrou o estudo sobre gêmeos que viviam sob uma mesma cultura, o contexto histórico-cultural também pode ser importante, se se considerar os sujeitos que vivem em culturas diferentes.

Foi o que perceberam Inglehart e Lingemann ${ }^{26}$ ao analisar, comparativamente, influências culturais e históricas sobre a felicidade expressa por indivíduos de vários países. Estes autores mostraram que fatores como religiosidade, nível de desenvolvimento econômico e regime de governo (especialmente, se o Estado é democrático ou não), dentre outros, também têm uma forte influência na explicação sobre os diferentes níveis de felicidade:

[...] these findings in no way refute the evidence that genetic factors play an important role in subjective well-being, but these findings indicate that genetic factors are only part of story. Happiness levels vary cross-culturally. Since cultures are constructed by human beings, this suggests that the pursuit of happiness is not completely futile. Genes may play a crucial role, but beliefs and values also are important. ${ }^{6}$

Por meio desse conjunto de estudos, é possível concluir que o comportamento humano resulta de causas complexas, oriundas tanto da cultura como de aspectos biológicos. Na situação atual,

20 SAHLINS, Marshall. 1976. The use and abuse of biology: an anthropological critique of sociobiology. Ann Arbor: University of Michigan Press, 1976.

21 LEWONTIN, Richard, ROSE, Steve \& KAMIN, Leon. Not in our genes: biology, ideology and human nature. New York: Pantheon, 1984.

22 ROGERS, Alan. Does biology constrain culture? American Anthropologist. Vol. 98, n 4, 1988.

23 PINKER, Steve. Why nature \& nurture don't go away? Deadelus. 2004.

24 PINKER, Steve. Why nature \& nurture don't go away? Deadelus. 2004.

25 LYKKEN, David; TELLEGEN, Auke. Happiness is a stochastic phenomenon. Psychological Science. Vol. 7, 1996.

26 INGLEHART, Ronald; LINGEMANN, Hans-Dieter. Genes, culture, democracy and happiness. 165183, 2002. Disponível em: www2000.wzb.eu/alt/iw/pdf/genecult.pdf. 
apesar de a controvérsia sobre o determinismo genético gerada na década de 70 ter perdido densidade e importância, aos interessados em uma boa revisão sobre as críticas à Sociobiologia recomenda-se Kirchof ${ }^{27}$.

A emergência da consciência humana, por meio da evolução de um cérebro mais complexo, foi um passo importante para que a evolução da linguagem ocorresse, adicionando a dimensão cultural à condição biológica. Desse modo, expressam-se os nossos comportamentos sob influências biológicas e culturais.

Enfim, a determinação genética que caracteriza biologicamente a individualidade é a matéria prima sobre a qual a cultura atua para nos caracterizar como seres sociais. Apesar de que as influências da genética e também do grupo sociocultural possam, em alguma medida, interferir sobre a formação da personalidade, reconhece-se como indivíduos dotados de subjetividade e personalidade distintas dos demais, o que confere certa autonomia. Seria essa condição de pessoas autônomas que reconheceria a felicidade como necessidade humana?

\section{FELICIDADE COMO NECESSIDADE HUMANA?}

O tema alusivo às necessidades humanas é sempre importante porque são elas que antecedem o surgimento de determinado Direito. Sobre a temática, importante referência nacional é o livro Miracy Barbosa de Sousa Gustin ${ }^{28}$, para quem as necessidades são, em geral, de natureza social e cultural. Mesmo as necessidades biológicas do homem são interpretadas conforme a influência da cultura e da sociedade, posto que variáveis segundo, por exemplo, os fatores geográficos, ambientais e temporais. É o homem, porém, o seu principal idealizador. Em virtude delas, o indivíduo apresenta as razões e os argumentos sobre a razão de ser das coisas e dos fatos.

Na síntese de Gustin ${ }^{29}$, as necessidades têm sido analisadas sob a perspectiva de quatro suposições. A primeira, diz respeito à sobrevivência dos indivíduos, daí a sua imprescindibilidade natural para qualquer ser humano (comida, alimentação, vestimenta). A despeito de sua exigência imperiosa e genérica, essas necessidades são historicamente apreciáveis porque sua satisfação é influenciada por elementos geográficos, sociais, culturais e temporais como já mencionado. A segunda suposição diz respeito à necessidade de integração social dos indivíduos. Por esta via, estima-se que o homem tem necessidade de trocar experiências, combinar a alocação social de bens e serviço, seguindo uma lógica distributiva e justa. Parte da pressuposição de que o homem é um ser social que necessita talhar normas de organização social para otimizar a coexistência. A terceira suposição é a de que o homem precisa de uma identidade a partir da qual define seu papel, suas escolhas e responsabilidades. E, pela crença e pela consciência de suas ações e escolhas, justifica sua responsabilidade no contexto social. Por fim, a última suposição é no sentido de afirmar a imprescindibilidade de favorecer a criatividade humana para otimizar a emancipação do homem em face das limitações e das restrições de ordem ambiental, natural ou mesmo cultural. Importa assegurar o progresso humano, o desenvolvimento do seu potencial.

As necessidades diferem dos meros desejos ou dos interesses por sua irresistibilidade. Correspondem às situações ou aos estados de caráter não intencional que podem afetar, positiva ou negativamente, a plenitude da pessoa ou das coletividades humanas. Impende saber como nascem essas necessidades, pois a ambiguidade, nesse aspecto, é inexorável à própria condição do homem, que já nem é capaz de distinguir, entre suas próprias necessidades, aquelas de origens pulsional ou cultural ${ }^{30}$.

Na perspectiva marxista, as necessidades são frutos do poder cognitivo, criativo e produtivo do homem. Marx, segundo Gustin ${ }^{31}$, não condenava a multiplicação das necessidades; do contrário,

27 KIRCHOF, Edgard Roberto. Estética e biossemiótica. Porto Alegre: EDIPUCRS, 2008.

28 GUSTIN, Miracy. Das necessidades humanas aos direitos: ensaio de sociologia e filosofia do direito. Belo Horizonte: Del Rey, 2009.

29 GUSTIN, Miracy. Das necessidades humanas aos direitos: ensaio de sociologia e filosofia do direito. Belo Horizonte: Del Rey, 2009. p. 10.

30 GUSTIN, Miracy. Das necessidades humanas aos direitos: ensaio de sociologia e filosofia do direito. Belo Horizonte: Del Rey, 2009. p. 106.

31 GUSTIN, Miracy. Das necessidades humanas aos direitos: ensaio de sociologia e filosofia do direito. 
admitia esse processo como parte do desenvolvimento do homem. ${ }^{7}$ Sua crítica se dirigia ao processo de criação de necessidades artificiais pela sociedade capitalista, determinadas em função da produção e do consumo para a valorização do capital e não para a emancipação do homem ${ }^{32}$.

$\mathrm{Na}$ medida em que as necessidades se voltam para a emancipação e para o desenvolvimento da humanidade, não há como negar o status de necessidade à autonomia. Por meio desta é que o homem progride, criando as condições de superação do seu sofrimento e promovendo a sua realização como um ser social típico ${ }^{33}$.

O homem difere dos demais animais principalmente pela autoconsciência, pela intencionalidade e pela linguagem, a partir das quais é capaz de refletir, reagir e recriar ${ }^{34}$. A autonomia é importante para a esfera privada, haja vista permitir a possibilidade de autoconstrução biográfica, e fundamental à esfera pública, uma vez que viabiliza a participação política da pessoa, essencial ao processo de consolidação da sociedade democrática.

Interessante observar, porém, que a autonomia é avaliável na dimensão relacional. O indivíduo reafirma sua importância e identifica as suas diversas necessidades na medida em que se relaciona com os demais. Por esta razão se diz que a autonomia requer uma validação intersubjetiva ${ }^{35}$. Nesse passo é que Sartre ${ }^{36}$ adverte que a nossa liberdade está sempre sob o olhar e o limite do outro. É nessa toada que o consórcio humano segue, em geral, o mesmo postulado de que a necessidade humana não poderá ser pautada na reificação do homem, o qual jamais poderá ser reduzido à condição de simples meio ${ }^{37}$.

Considerando a breve explanação sobre necessidade como algo irresistível à emancipação humana, poder-se-ia afirmar a felicidade como um tipo de necessidade?

Gustin $^{38}$ adverte que a privação daquilo que é básico e imprescindível à pessoa pode gerar um estado de degeneração da qualidade da vida e do bem-estar que sua satisfação pode promover. Sob essa ótica, a resposta seria positiva se se correlacionar felicidade à qualidade de vida ou mesmo ao sentimento de bem-estar. Porém, a despeito do bem-estar que a satisfação das necessidades humanas promove, sua perenidade não é inexorável. Após satisfeita uma necessidade, surgem outras que, mais uma vez, motivam o homem a seguir em sua direção, gerando-lhe a satisfação ou a frustração pela insatisfação.

Seguindo a perspectiva marxista de que a liberdade como forma de emancipação do homem possibilita o desenvolvimento exponencial de suas potencialidades, ter-se-ia que a liberdade e o trabalho seriam necessidades humanas indispensáveis ao seu desenvolvimento ${ }^{39}$. Mas aqui, essa emancipação não necessariamente seria sinônimo de felicidade.

$\mathrm{Na}$ orientação freudiana, as necessidades do homem estão relacionadas à fome ou ao amor, agentes poderosos que o levam a estímulos pulsionais de conservação e de ordem sexual. $\mathrm{Na}$ medida em que ocorre a satisfação das necessidades então emergentes, o indivíduo experimenta um prazer que se confunde com a própria felicidade ${ }^{40}$.

Belo Horizonte: Del Rey, 2009. p. 74 e ss.

32 GUSTIN, Miracy. Das necessidades humanas aos direitos: ensaio de sociologia e filosofia do direito. Belo Horizonte: Del Rey, 2009. p. 93.

33 GUSTIN, Miracy. Das necessidades humanas aos direitos: ensaio de sociologia e filosofia do direito. Belo Horizonte: Del Rey, 2009. p. 19.

34 GUSTIN, Miracy. Das necessidades humanas aos direitos: ensaio de sociologia e filosofia do direito. Belo Horizonte: Del Rey, 2009. p. 89.

35 GUSTIN, Miracy. Das necessidades humanas aos direitos: ensaio de sociologia e filosofia do direito. Belo Horizonte: Del Rey, 2009. p. 21.

36 SARTRE, Jean Paul. O ser e o nada. Ensaio da ontologia fenomenológica. São Paulo: Vozes, 2009.

37 KANT, Immanuel. Fundamentação da metafísica dos costumes e outros escritos. Trad. Leopoldo Holzbach. São Paulo: Martin Claret, 2011.

38 GUSTIN, Miracy. Das necessidades humanas aos direitos: ensaio de sociologia e filosofia do direito. Belo Horizonte: Del Rey, 2009. p. 14.

39 GUSTIN, Miracy. Das necessidades humanas aos direitos: ensaio de sociologia e filosofia do direito. Belo Horizonte: Del Rey, 2009. p. 96.

40 FREUD, Sigmund. O mal-estar na civilização. Sigmund Freud, Obras completas, vol. 18, Trad. Paulo César de Souza. São Paulo: Editora Companhia das Letras, 2010. p. 30 e ss. 
Assim, a palavra felicidade estaria associada à experiência de intensos sentimentos de prazer $^{41}$. Em vista disso, a busca da felicidade seria a intenção primária da vida de qualquer homem. ${ }^{9}$ Nada obstante, as circunstâncias gerais e ordinárias opõem-se, continuamente, a essa empresa de ser feliz. A infelicidade é a experiência mais comum e corriqueira, originária daquele sofrimento que ameaça a partir de três direções: do nosso corpo que, condenado à decadência e à morte, experimenta a dor até mesmo como advertência do perigo; do mundo externo, que pode se voltar contra nós com poderosas e devastadoras forças; e, por último, do relacionamento com os outros homens, fonte de grandes frustrações ${ }^{42}$. Ante a constante ameaça de infelicidade, das possibilidades de sofrimento, os homens podem se contentar em definir a felicidade pela ausência de infelicidade. Escapando da infelicidade, o homem já poderia dizer-se feliz. E agora, seria possível tratar de um direito de não ser infeliz?

\section{ENTRE O DIREITO DE SER FELIZ E O DIREITO À BUSCA DA FELICIDADE}

Jeremy Bentham, ainda no século XVIII, sustentava que aos Estados incumbia promover a felicidade dos seus cidadãos pela punição e pela recompensa. ${ }^{10}$ Sua filosofia, denominada de utilitarismo ${ }^{11}$, propunha que todos deveriam buscar a máxima felicidade para o maior número de pessoas. Entendia a felicidade como o sentimento subjetivo de prazer e isenção de dor. Assim, a bondade de uma ação, em seu juízo, não deveria ser aferida pelo aspecto intencional, mas em razão de seus efeitos sobre a felicidade humana.

O utilitarismo Benthaniano como guia moral da felicidade pode fundamentar leis penais e civis, bem como inspirar a elaboração de políticas públicas para a promoção da felicidade ${ }^{43}$. Por meio de uma economia de bem-estar, o utilitarismo orientou o pensamento econômico até a década de 30 , com certo fôlego, quando a base científica das comparações interpessoais foi questionada ${ }^{44}$.

A partir da década de 90, a economia retoma (mais intensivamente) os estudos sobre a temática e, atualmente, fala-se em níveis de felicidade individual e coletivo. O primeiro nível considera a subjetividade de cada cidadão, e o segundo diz respeito às condições habitacionais disponíveis, aos equipamentos públicos voltados para a promoção da saúde, da educação e do lazer, às ofertas de emprego, favorecendo o clima de confiança e de estabilidade social ${ }^{45}$. A análise de Ruuh Veenhoven ${ }^{46}$ identifica quatro determinantes gerais imprescindíveis para a mensuração do indicador de felicidade, quais sejam, a qualidade ambiental do entorno, a capacidade da pessoa para viver, a utilidade social da vida e o desfrute subjetivo da vida. A qualidade ambiental do entorno evoca a necessidade de um meio ambiente ecologicamente equilibrado como essencial à vida, incluindo-se aqui a qualidade do espaço urbano quanto à organização dos equipamentos da cidade e a sua funcionalização para o bem-estar das pessoas. É possível, portanto, observar que esse interesse já é objeto das preocupações do Direito, especialmente dos sub-ramos Direito Ambiental e Direito Urbanístico. No Brasil, o meio ambiente ecologicamente equilibrado é considerado um direito fundamental (art. 225, CF/88), constituindo pauta importante das políticas públicas federal, estadual e municipal. 0 segundo item diz respeito à capacidade que a pessoa tem de enfrentar os problemas da vida, de projetar e realizar seus anseios. Talvez se possa articular esse item à autonomia ético-existencial do indivíduo, muito bem instrumentalizada juridicamente pelo conjunto de direitos fundamentais e

41 FREUD, Sigmund. O mal-estar na civilização. Sigmund Freud, Obras completas, vol. 18, Trad. Paulo César de Souza. São Paulo: Editora Companhia das Letras, 2010. p. 30.

42 FREUD, Sigmund. O mal-estar na civilização. Sigmund Freud, Obras completas, vol. 18, Trad. Paulo César de Souza. São Paulo: Editora Companhia das Letras, 2010. p. 31.

43 VEENHOVEN, Ruut. Medidas de la Felicidad Nacional Bruta. Intervención Psicosocial. Revista sobre Igualdad y Calidad de Vida. Vol. 18 n. ${ }^{0}$ 3, 2009, p.279-299. Disponível em: http://www2.eur.nl/ fsw/research/ veenhoven/Pub2000s/2009j-fulls.pdf. p. 280.

44 SEN, Amartya. A idéia de justiça. São Paulo: Companhia das Letras, 2011. p. 311.

45 VEENHOVEN, Ruut. Medidas de la Felicidad Nacional Bruta. Intervención Psicosocial. Revista sobre Igualdad y Calidad de Vida. Vol. 18 n. ${ }^{0}$ 3, 2009, p.279-299. Disponível em: http://www2.eur.nl/ fsw/research/veenhoven/Pub2000s/2009j-fulls.pdf. p. 281.

46 VEENHOVEN, Ruut. Medidas de la Felicidad Nacional Bruta. Intervención Psicosocial. Revista sobre Igualdad y Calidad de Vida. Vol. 18 n. ${ }^{0} 3$, 2009, p.279-299. Disponível em: http://www2.eur.nl/ fsw/research/veenhoven/Pub2000s/2009j-fulls.pdf. 
pela cláusula geral de tutela. ${ }^{12} \operatorname{Sen}^{47}$ chama, a essa variável, capacidade. $O$ terceiro ponto estaria relacionado à utilidade social da vida para o seu entorno (a comunidade), o que remete à ideia de capacidade criativa e de solidariedade. E, por fim, a apreciação subjetiva da vida pelo próprio sujeito, em termos semelhantes àquela percepção de que fala a teoria do utilitarismo, ou seja, aquilo que envolve seu prazer, sua alegria. Mais uma vez cogitam-se das escolhas apuradas pela autonomia.

A compreensão de felicidade coletiva teria referência aos termos bem-estar e à qualidade de vida, referidos como objetos do indicador de desenvolvimento - Felicidade Interna Bruta (FIB). ${ }^{13}$ Pelo FIB, avaliam-se as condições econômicas, sociais e ambientais que o Estado oferece para maximizar a qualidade de vida das pessoas sob seu território, mensurando-se, assim, o nível de desenvolvimento.

Observe-se que o indicador citado considera outros elementos além da capacidade econômica da pessoa. $\mathrm{Na}$ explicação de $\mathrm{Sen}^{48}$, a noção felicidade escapa dos limites estabelecidos pela relação com a renda, ${ }^{14}$ pois outros elementos devem ser considerados, a exemplo do impacto que os sucessos e os fracassos têm sobre o estado de felicidade da pessoa ${ }^{49}$. Isso remete à importância da atuação criativa do homem na construção de sua história, pela idealização e pela execução de seus projetos e, nesse aspecto, relembra-se a observação de Freud $^{50}$ sobre o prazer e a felicidade que a realização de algo pode trazer: o gozo que tem o artista em criar, ao dar corpo às suas fantasias; a alegria do pesquisador na solução do problema ou na apreensão da verdade etc.

Pela importância valorativa que a pessoa alcançou na ordem jurídica ocidental, conjugando em torno de si uma soma de direitos, a felicidade parece se converter em algo inexorável. Todos querem ser felizes e julgam ter, inclusive, um direito à felicidade. Porém, se já não é fácil a análise da felicidade sob as perspectivas de ciências como a biologia, a sociologia, a filosofia e até mesmo a economia, tampouco o será no âmbito do Direito.

A concepção psicanalítica de felicidade, aliada ao prazer e à ausência de sofrimento, parece escapar aos domínios do Direito, uma vez que nem toda experiência de sofrimento pode ser afastada por meio de normas jurídicas, por exemplo. É certo que as pessoas têm que ter oportunidade de minimizar os danos, as privações ou os sofrimentos graves que atuam negativamente no plano de suas vidas, mas nem todos os danos são reparáveis. A vida traz experiências negativas que o convívio social, a ciência e o direito não têm forças para afastar. Mais coerente é aceitar a autonomia como uma necessidade ${ }^{51}$ e compreendê-la como um importante instrumento para busca da felicidade ou para o afastamento da infelicidade.

Portanto, se o Direito não pode assegurar a felicidade como prazer ou mesmo como ausência de sofrimento, poderá assegurar o livre desenvolvimento das potencialidades criativas do sujeito para que este possa se proteger do que lhe perturba e perseguir o que Ihe traz prazer, satisfação e crescimento. ${ }^{15}$ Assim, a autonomia seria a necessidade singular e primordial do ser humano para a construção plena de seu bem-estar e de sua realização. Mesmo na contemporaneidade, considerada a heterogeneidade de visões sobre o ser humano, há uma defesa comum da emancipação e da autorrealização humana. ${ }^{16}$

O ser humano é dotado de múltiplas potencialidades e tem a necessidade de projetá-las, de sorte que sua felicidade parece estar relacionada ao grau de desenvolvimento dessas potencialidades, conforme Franklin ${ }^{52}$. Felicidade seria o produto do fulfillment. ${ }^{17}$ Logo, não é o prazer por si que traz a felicidade, mas sim o grau de realização das potencialidades. A momentânea sensação prazerosa, por exemplo, aquela provocada pelo uso de drogas, por não implicar autorrealização da pessoa, em nada terá a ver com felicidade.

Se se voltar na história para analisar o conteúdo do direito à busca da felicidade arrolado ao lado do direito à vida e à propriedade na Declaração da Independência, em 1776, ${ }^{18}$ ainda aí, custa crer

47 SEN, Amartya. A idéia de justiça. São Paulo: Companhia das Letras, 2011.

48 SEN, Amartya. A idéia de justiça. São Paulo: Companhia das Letras, 2011. p. 206.

49 SEN, Amartya. A idéia de justiça. São Paulo: Companhia das Letras, 2011. p. 311.

50 FREUD, Sigmund. O mal-estar na civilização. Sigmund Freud, Obras completas, vol. 18, Trad. Paulo César de Souza. São Paulo: Editora Companhia das Letras, 2010. p. 35.

51 GUSTIN, Miracy. Das necessidades humanas aos direitos: ensaio de sociologia e filosofia do direito. Belo Horizonte: Del Rey, 2009. p. 15.

52 FRANKLIN, Samuel. The psychology of happiness. Cambridge University Press, New York, 2010. p. 10. 
que Thomas Jeferson estivesse falando apenas da busca pelo prazer. Talvez, já estivesse pensando na liberdade que é pré-condição da autonomia e, em consequência, da autorrealização. Considerando o perfil da pessoa de Thomas Jeferson, muito provavelmente este se referia à busca da felicidade como a liberdade de cada cidadão em perseguir seu sonho em atenção às suas potencialidades e às suas capacidades. ${ }^{19}$

O dinheiro, a saúde e o meio ambiente saudável podem ter importância na definição de felicidade. Até mesmo a fé em Deus e a pertinência a uma religião podem ampliar as condições de felicidade. Há estudos considerando a importância desses fatores, como explica Franklin ${ }^{53}$. Pela autonomia, nada impede que o sujeito possa buscar a felicidade por meio dessas instâncias.

Assim, quando se pretende juridicizar algo a respeito da felicidade, só se pode falar do direito à liberdade, à autonomia para a busca da felicidade. Há também que se disciplinar sobre as condições materiais imprescindíveis à realização dessa autonomia, indispensáveis para que a pessoa possa desenvolver suas capacidades e sua personalidade. Há um conjunto de pressupostos essenciais, a exemplo do meio ambiente ecologicamente equilibrado, da qualidade do espaço urbano, do acesso aos direitos sociais como saúde, educação, segurança e transporte, dentre outros.

Disso se deduz que a emancipação da pessoa humana não se confina no âmbito do direito privado. Como um valor que se espraia por todo o ordenamento jurídico, a tutela da pessoa se estabelece pela conjugação de uma série de instrumentos de direito público e privado em seu favor ${ }^{54}$. Uma sociedade democrática, focada na pessoa, busca a realização da justiça seja no plano retributivo ou no plano distributivo, de sorte a possibilitar a todos o bem-estar.

Em face dessa necessária mesclagem entre público e privado, houve autores mais apegados à noção de direito de personalidade atrelada à forma de direito subjetivo que suscitaram a existência dos direitos de personalidade sociais - exatamente tutelando aqueles interesses indispensáveis à formação e ao desenvolvimento da pessoa, mas situados na esfera prestacional dos direitos públicos. ${ }^{21}$ Ainda que vinculada às categorias patrimonialistas do direito civil tradicional, tal concepção revela a necessidade de articulação do público e do privado para a tutela integral da pessoa.

Voltando à pergunta antes formulada, sobre a conformação da felicidade como uma necessidade humana, tem-se que: embora não seja considerada uma necessidade, a busca da felicidade tem sido identificada pela jurisprudência brasileira ${ }^{22}$ como um postulado confluente do princípio da dignidade da pessoa humana e correlacionado ao exercício da autonomia e da emancipação. No âmbito do direito de família são várias as decisões prolatadas pelo Superior Tribunal de Justiça, identificando a busca da realização pessoal, traço inequívoco do direito de personalidade, com a busca da felicidade ${ }^{23}$

Nessa perspectiva, não se pode prescrever um direito de ser feliz, muito embora se possa estabelecer o direito à busca da felicidade, assegurando a liberdade geral, a autonomia relacional e as condições materiais indispensáveis ao desenvolvimento da pessoa.

Tramita no Congresso Nacional, desde 2010, um Projeto de Emenda Constitucional (PEC no.19/10), de autoria do então Senador Cristóvão Buarque, que visa alterar a redação do artigo sexto para incluir o direito fundamental à busca da felicidade no rol dos direitos sociais. A busca da felicidade passaria a condição de direito fundamental como a educação, a saúde, a alimentação, o trabalho, a moradia, o lazer, a segurança, a previdência social, a proteção à maternidade e à infância, a assistência aos desamparados. O objetivo da PEC seria o de fortalecer a importância da dignidade da pessoa humana no imaginário da sociedade e não o de estimular anseios egoísticos individualistas. ${ }^{24}$

A PEC reitera o raciocínio que este texto vem desenvolvendo, no sentido de que o direito à busca da felicidade é garantido, na medida em que o Estado oferece aos cidadãos o efetivo acesso aos demais direitos, sejam eles individuais, políticos ou sociais.

Além dos EUA, outros países consignaram o direito à busca da felicidade nas suas respectivas constituições, a exemplos do Japão e da Coréia do Sul. ${ }^{25} \mathrm{~A}$ Organização das Nações Unidas, por seu turno, aprovou Resolução ${ }^{26}$, que reconhece a busca da felicidade como um objetivo fundamental humano ao tempo em que convidou os cento e noventa e três países membros a refletirem sobre a

53 FRANKLIN, Samuel. The psychology of happiness. Cambridge University Press, New York, 2010.

54 PERLINGIERI, Pietro. La personalità umana nell'ordinamento giuridico. Napoli: Edizione Scientifica Italiana, 1972. p. 16 e ss. 
importância deste objetivo em suas políticas públicas. A tendência é pela formulação de um indicador de desenvolvimento semelhante àquele instituído no Butão, qual seja, o já citado FIB. Essa questão, aliás, mereceu a atenção de uma das comissões que compuseram a Conferência Rio +20.

\section{CONCLUSÕES}

O conceito de felicidade não encontra consenso em nenhuma das áreas do conhecimento, ao longo de todos os tempos, mesmo tendo sido reiteradamente discutido. $\mathrm{O}$ interesse sobre o tema chega ao setor da economia, em vista da influência do pensamento utilitarista de Bentham, passando por diversas transformações até se delinear uma compreensão de felicidade atenta a uma série de fatores internos e também externos. Já no século XXI, a felicidade se torna um indicador de desenvolvimento econômico, uma vez que se considera o FIB - Felicidade Interna Bruta.

Embora Thomas Jefferson tenha incluído o direito à busca da felicidade na Declaração da Independência dos EUA (1776), a temática ganha uma dimensão mais ampla nos dias atuais, conquistando a atenção do Direito em diversas partes do mundo.

No entanto, não coube à Ciência do Direito a proposição de assegurar a cada indivíduo o direito à felicidade, nem poderia fazê-lo, haja vista a plasticidade e a subjetividade do conceito de felicidade. Ainda que considerados os fatores biológicos e culturais acerca da felicidade individual, os limites e as possibilidades jurídicas sobre a temática não podem encerrar uma preocupação em garantir um sentimento de felicidade, mas se voltam a permitir a movimentação do sujeito na direção daquilo que supostamente o fará feliz.

Entende-se que, independentemente das diferenças entre concepções distintas sobre o conceito felicidade, os estados emocionais que um indivíduo possa experimentar e reconhecer como sensações de felicidade dificilmente serão atingidos sem o suprimento das necessidades básicas necessárias à manutenção da sua higidez física e mental. Não há felicidade sem pão, sem roupa e sem saúde.

Assim, poderá o Direito ocupar-se em tutelar a pessoa no que toca às suas necessidades, aqui entendidas como aquelas condições irrecusáveis para o desenvolvimento do homem, a considerar o seu contexto histórico-social e cultural. Seriam os elementos indispensáveis ao desenvolvimento do homem e à busca pela felicidade o foco da preocupação jurídica.

Essa conclusão independe inclusive das influências majoritárias que a cultura ou a biologia possam exercer sobre o estado de bem-estar. Demais, não há evidências conclusivas que subsidiem o reconhecimento inequívoco de preponderância da cultura sobre a biologia e vice-versa como causas efetivas de sentimentos de felicidade. Assim, tanto a biologia quanto a cultura desempenham papéis importantes como causas da expressão de felicidade dos indivíduos.

Por outro lado, a liberdade de decisão sobre questões que afetam sua vida, além de ser um componente importante da autonomia, é condição necessária para que o indivíduo alcance a felicidade entendida como um estado duradouro de satisfação pessoal.

Nessa perspectiva, considera-se a autonomia do indivíduo em tomar as decisões sobre seu destino um aspecto que influencia de forma intensa sobre a realização de suas potencialidades e, por conseguinte, em sua capacidade de ser feliz. Um indivíduo dependente emocional ou financeiramente de certo estará tolhido em sua capacidade de decidir sobre quais atitudes adotar diante dos obstáculos que possam dificultar ou impedir a expressão de sua potencialidade criativa. Nesse aspecto importante da realização pessoal, uma educação que proporcione ao individuo as condições para sua emancipação é indispensável. Se não cabe ao Direito garantir a felicidade, poderá disciplinar as condições essenciais a que o próprio sujeito se mova em sua direção. Logo, no âmbito jurídico, é possível tratar de um direito à busca da felicidade cuja correlação é fortíssima com a garantia dos direitos fundamentais individuais, coletivos, sociais e políticos.

Por fim, dirigem-se agradecimentos especiais ao Professor Doutor Lorenzo Roberto Sgobaro Zanette e ao aluno Diogo Portela por suas valiosas contribuições na revisão deste texto. 
1 Heródoto (485 a 420 a.C.) considerava um homem feliz apenas se após sua morte fosse constatado que superou os obstáculos encontrados em vida ${ }^{55}$. Para Heródoto as manifestações volitivas individuais não entravam em questão, mas sim o padrão uniforme de conduta existencial. Note-se que embora defendesse uma ideia supostamente objetiva sobre felicidade, Heródoto excluía a variedade de concepções subjetivas que poderiam ser expressas. O que talvez propusesse era uma norma de conduta para todos os indivíduos daquela sociedade.

2 Segundo Aristóteles (1984, p. 52), para o homem vulgar a felicidade pode se confundir com os prazeres, a vida dos gozos; para o político, a felicidade se confunde com a sua honra - a finalidade da vida política. "Os homens buscam a honra para se convencerem a si mesmos de que são bons". Contudo "a virtude é mais excelente. Poder-se-ia supor que a virtude e não a honra é a finalidade da vida política. Mas também ela parece ser de certo modo incompleta, porque pode acontecer que seja virtuoso quem está dormindo, quem leva a vida inteira de inatividade e, mais ainda, é ela incompatível com os maiores sofrimentos e infortúnios".

3 "E, no entanto, como dissemos, ela necessita igualmente dos bens exteriores; pois é impossível, ou pelo menos não é fácil, realizar atos nobres sem os devidos meios. Em muitas ações utilizamos como instrumentos os amigos, a riqueza e o poder político; e há coisas, cuja ausência empana a felicidade, como a nobreza de nascimento, uma boa descendência, a beleza. Com efeito, o homem de muito feia aparência ou mal-nascido ou solitário e sem filhos, não tem muitas probabilidades de ser feliz, e talvez tivesse menos ainda se seus filhos ou amigos fossem visceralmente maus e se a morte lhe houvesse roubado bons filhos ou bons amigos" (ARISTÓTELES, 1984, p. 58).

4 Para ser feliz "é preciso apagar o que é imaginação, reprimir impulsos, apagar o desejo, continuar senhor de sua faculdade diretiva. Viver no presente, ajudar seus semelhantes, contentar-se com tudo o que acontece. A justificativa é que faço parte de um grande todo do qual sou uma engrenagem; ao perseguir minha própria perfeição moral e racional, participo do bom funcionamento do conjunto, da harmonia cósmica, e isso é a felicidade. De escravo a imperador, cada um é importante, e todo mundo pode ser feliz"

5 Uma abordagem psicanalítica sobre a felicidade na pós-modernidade pode ser encontrada em Freud $^{57}$ e Franco Filho ${ }^{58}$

6 "Esses resultados de forma alguma refutam o papel importante que fatores genéticos exercem sobre o bem-estar individual, mas indicam que a genética é apenas uma parte da história. Níveis de felicidade variam entre culturas e, considerando que culturas são construídas por seres humanos, isso sugere que a busca da felicidade não é inteiramente despropositada. Os genes podem ter um papel crucial, mas crenças e valores também são importantes" (tradução livre).

7 As necessidades são, portanto, determinadas pelos fatores sociais em cada momento histórico e em cada espaço social. Para Marx, as necessidades são produto da ação humana. Sua teoria demonstra que o aumento e a evolução das necessidades decorrem do processo de objetivação, ou seja, o processo interativo em que o sujeito, por meio de sua ação continua, produz objetos em função de suas necessidades e, ao fazê-lo também se transforma. Uma vez satisfeita as primeiras necessidades, a própria satisfação e o instrumento utilizado para tal, já conduz à produção de novas necessidades ${ }^{59}$.

8 Considera autônomo "aquele que é capaz de fazer escolhas próprias, de formular objetivos pessoais respaldados em convicções e de definir estratégias mais adequadas para atingi-los. Em termos mais restritos, o limite da autonomia equivaleria à capacidade de ação e de intervenção da pessoa ou do grupo sobre as condições de sua forma de vida" 60.

9 Segundo Freud, "o que revela a própria conduta dos homens acerca da finalidade e intenção de sua vida, o que pedem eles da vida e desejam alcançar? É difícil não acertar a resposta: eles buscam a

55 MCMAHON, Darrin. Felicidade: uma história. São Paulo: Editora Globo, 2006.

56 MINOIS, Georges. A idade de outro. História da busca da felicidade. São Paulo: Editora UNESP, 2011. p. 64.

57 FREUD, Sigmund. O mal-estar na civilização. Sigmund Freud, Obras completas, vol. 18, Trad. Paulo César de Souza. São Paulo: Editora Companhia das Letras, 2010.

58 FRANCO FILHO, Odilon de Melo. A civilização do mal estar pela não-felicidade. Revista brasileira de psicanálise Vol. 43, n², 183-192, 2009.

59 GUSTIN, Miracy. Das necessidades humanas aos direitos: ensaio de sociologia e filosofia do direito. Belo Horizonte: Del Rey, 2009. p. 88.

60 GUSTIN, Miracy. Das necessidades humanas aos direitos: ensaio de sociologia e filosofia do direito. Belo Horizonte: Del Rey, 2009. p. 20. 
felicidade, querem se tornar e permanecer felizes ${ }^{61}$.

10 Em Bentham, "A parte da missão de governo consiste em punir constitui mais particularmente o objeto da lei penal. A obrigatoriedade ou necessidade de punir uma ação é proporcional à medida que tal ação tende a perturbar a felicidade e à medida que a tendência do referido ato é perniciosa. Ora, a felicidade consiste naquilo que já vimos, ou seja, em desfrutar prazeres e estar isento de dores" ${ }^{162}$.

11 Na explicação de SEN ${ }^{63}$, "a economia do bem-estar concedeu à felicidade o status de importância única na avaliação do bem-estar e da vantagem humana, colocando-a como a base da avaliação social e de elaboração das políticas públicas. O utilitarismo foi por um tempo muito longo algo como 'a teoria oficial da economia do bem-estar, embora (como mostra a brilhante análise de John Roemer) hoje existam muitas teorias atrativas".

12 Em face da importância da pessoa para a ordem jurídica, sua tutela deve-se fazer por meio de uma norma aberta, expandindo o valor protetivo por todo o sistema jurídico. Para Perlingieri64, essa tutela deve ser operacionalizada por meio de norma tanto mais ampla quanto possível para garantir a plena liberdade de desenvolvimento da pessoa. Em outro texto, em suas próprias linhas, Perlingieri65 afirma que "A personalidade é, portanto, não um direito, mas um valor (o valor fundamental do ordenamento) e está na base de uma série aberta de situações existenciais, nas quais se traduz a sua incessantemente mutável exigência de tutela. Tais situações subjetivas não assumem necessariamente a forma do direito subjetivo e não deve fazer perder de vista a unidade do valor envolvido. Não existe um número fechado de hipóteses tuteladas: tutelado é o valor da pessoa sem limites, salvo aqueles colocados no seu interesse e naqueles de outras pessoas. A elasticidade torna-se instrumento para realizar formas de proteção também atípicas, fundadas no interesse à existência e no livre exercício da vida de relações." No Brasil, o estudo da cláusula geral de tutela fica bem claro nas explicações de Tepedino ${ }^{66}$ e Moraes ${ }^{67}$.

13 O indicador FIB - Felicidade Interna Bruta, ou em língua inglesa Gross National Happiness (GNH) tem origem no Butão e se presta a mensurar o progresso nacional a partir da capacidade do Estado de promover as condições materiais de felicidade ${ }^{68}$. O FIB à semelhança do PIB, que diz respeito às riquezas produzidas pelo país, mede a capacidade de o país de prover as condições materiais para que resulte em felicidade de seus cidadãos. O FIB baseia-se em nove indicadores: padrão de vida, saúde da população, educação, vitalidade e diversidade do ecossistema, vitalidade e diversidade cultural, uso e balanceamento do tempo utilizado, boa governança, vitalidade da comunidade e bem-estar emocional (Bandhyopadhyay, 2007. Microfinance in improvement of living standard and GNH. http:// www.gnh-movement.org/callpapers_detail.php?id=81). Em contraste, apesar de teoricamente ser a mesma coisa, o índice de felicidade interna (IFI), que também inclui nove indicadores, alguns deles são diferentes, como se pode notar: bem estar material, saúde, estabilidade política, vida em família, vida em comunidade, clima e geografia, trabalho, liberdade política e igualdade entre os sexos ("Índice de Felicidade Interna, o Produto Interno Bruto das Nações e outros Indicadores Quantitativos. Um Estudo sobre as suas relações" de Cássia Regina Vanícola (cassiavanicola@ig.com.br) - Pontifícia Universidade Católica - SP). Apesar de não se referir explicitamente à autonomia como uma característica da personalidade importante para que o indivíduo possa atingir esse estado de felicidade interna, podemos considerá-la indispensável para tal fim e mesmo assumir que sem autonomia é difícil sentir-se feliz.

14 Citando Richard Layard e seu livro "Happiness: lessons from a new science", adverte sobre "o paradoxo que constitui a nossa vida, pois a maioria das pessoas quer mais renda e luta por ela. No entanto, à medida que as sociedades ficam mais ricas, suas populações não se tornam mais felizes"69.

15 "Em face disso, supõe-se que a precondição indispensável para que isso ocorra é desenvolver no ser humano a condição de autonomia, uma condição genericamente necessária e indispensável à atu-

61 FREUD, Sigmund. O mal-estar na civilização. Sigmund Freud, Obras completas, vol. 18, Trad. Paulo César de Souza. São Paulo: Editora Companhia das Letras, 2010. p. 29-30.

62 BENTHAM, Jeremy. Uma introdução aos princípios da moral e da legislação. Os pensadores. Trad. Luiz João Baraúna. São Paulo: Abril Cultural, 1984. p. 19.

63 SEN, Amartya. A idéia de justiça. São Paulo: Companhia das Letras, 2011. p. 306.

64 PERLINGIERI, Pietro. La personalità umana nell'ordinamento giuridico. Napoli: Edizione Scientifica Italiana, 1972. p. 12.

65 PERLingieRI, Pietro. Perfis de direito civil. Rio de Janeiro: Renovar, 2007. p. 155.

66 TEPEDINO, Gustavo. Temas de direito civil. Vol. 1. Rio de Janeiro: Renovar, 2001.

67 MORAES, Maria Celina. Na medida da pessoa humana. Estudos de direito civil-constitucional. Rio de Janeiro: Renovar, 2010.

68 GRAHAM, Carol. Happiness around the world: the paradox of happy peasants and miserable millionaires. New York: Oxford University Press, 2009. p. 21.

69 SEN, Amartya. A idéia de justiça. São Paulo: Companhia das Letras, 2011. p. 307. 
ação do ser humano - individual ou coletivo - no sentido de criar ou recriar condições que permitam a superação de seus sofrimentos graves, sua realização como ser típico na sociedade e, ao mesmo tempo, sua liberação de constrangimentos internos e externos"70.

16 De acordo com Franklin71, "The humanists bring us to our final meaning of happiness and the one to which this book is devoted: Happiness is the fulfillment of human potential. Happiness is not only about feeling good or being wealthy or being holy. Rather, happiness is fulfilling our inherent possibilities, or, as the U.S. Army commercial says, "be[ing] all that [we] can be. To live well we humans must, like other creatures, be what we are meant to be."

17 Ainda com Franklin72, "Pleasure is not the cause of happiness but often the by-product of fulfillment. And we must be careful because not all pleasures derive from fulfillment. The good feelings produced by drugs, alcohol, or an extravagant shopping spree can trick and misdirect us. It is actualization, not pleasure, that is the key to a good life".

18 We hold these truths to be self-evident, that all men are created equal, that they are endowed by their creator with certain unalienable Rights, that among these are Life, Liberty and the pursuit of Happiness. Thomas Jefferson, The Declaration of Independence, 1776.

19 Jefferson's life could not be described as fun filled or pleasure seeking. Money was important to him and he abhorred debt, but people who value money greatly are usually careful with it and don't die broke as the third President did. Further, Jefferson was not a terribly religious person. Many of the founding fathers, including Jefferson, were deists, not devoutly Christian at all. Deists were influenced by the development of Renaissance science that flourished during their time. For the Deist, God was not a personal God at all but rather the creator of an orderly, knowable world. God did not intervene in the affairs of men. It is doubtful that Jefferson's kind of happiness would be tied to such a God. While we might argue over Jefferson's view of happiness, it is unlikely that he was advocating the pursuit of pleasure, wealth, or God. The founding of America was not far removed from European feudal society where many were confined to serfdom under the heavy hands of feudal lords. These were the conditions that early immigrant Americans sought to escape. They dreamed of a place where they could live safely and freely, and where the pursuit of dreams was possible. The Declaration of Independence guarantees that potential, not heritage, defines one's limits. A new nation needs good citizens. Jefferson may well have realized that the right of each individual to pursue his or her dreams might build a nation worthy of the risk taken by the heroic Founding Fathers. Jefferson could not guarantee a perfect life to everyone, but he may have intended the government to ensure the right of every American to pursue all that his or her natural abilities would allow ${ }^{73}$.

$20 \mathrm{Na}$ expressão de Perlingieri, "benessere generale, in una società democratica, significa giustizia non sotanto retributive ma distributive, cio è benessere generalizzato, presente in tutte le persone ed in tutte comunità. Realizzate tutte le libertà e tutti i diritti enunciate dalla Dichiarazione, si potrà affermare I'esistenza di una società democratica"(PERLINGIERI, 1976, p. 52).

21 Os direitos de personalidade sociais, segundo os que adotam esta corrente, seriam determinados direitos originários da evolução de certos direitos humanos de categoria social e econômica, surgindo entre os direitos de personalidade à saúde, o direito do trabalho, o direito à informação, o direito ao silencio e assim sucessivamente. Como a maioria desses direitos não se constituem como direitos subjetivos, e os direitos de personalidade, tipificados como direitos sociais, podem ser enquadrados tanto entre os direitos de personalidade públicos como os privados, de acordo com a espécie, preferem, os civilistas, na sua grande maioria, apenas dividir os direitos de personalidade em públicos e privados ${ }^{74}$.

22 O DIREITO À BUSCA DA FELICIDADE, VERDADEIRO POSTULADO CONSTITUCIONAL IMPLÍCITO E EXPRESSÃO DE UMA IDÉIA-FORÇA QUE DERIVA DO PRINCÍPIO DA ESSENCIAL DIGNIDADE DA PESSOA HUMANA - ALGUNS PRECEDENTES DO SUPREMO TRIBUNAL FEDERAL E DA SUPREMA CORTE AMERICANA SOBRE O DIREITO FUNDAMENTAL À BUSCA DA FELICIDADE. O princípio constitucional da busca da felicidade, que decorre, por implicitude, do núcleo de que se irradia o postulado da dignidade da pessoa humana, assume papel de extremo relevo no processo de afirmação, gozo e expansão dos direitos fundamentais, qualificando-se, em função de sua própria teleologia, como fa-

70 GUSTIN, Miracy. Das necessidades humanas aos direitos: ensaio de sociologia e filosofia do direito. Belo Horizonte: Del Rey, 2009. p. 15.

71 FRANKLIN, Samuel. The psychology of happiness. Cambridge University Press, New York, 2010. p. 8-9.

72 FRANKLIN, Samuel. The psychology of happiness. Cambridge University Press, New York, 2010. p. 19.

73 FRANKLIN, Samuel. The psychology of happiness. Cambridge University Press, New York, 2010. p. $10-11$.

74 SZANIAWSKI, Elimar. Direitos de personalidade e sua tutela. São Paulo: RT, 1993. p. 51. 
tor de neutralização de práticas ou de omissões lesivas cuja ocorrência possa comprometer, afetar ou, até mesmo, esterilizar direitos e franquias individuais. - Assiste, por isso mesmo, a todos, sem qualquer exclusão, o direito à busca da felicidade, verdadeiro postulado constitucional implícito, que se qualifica como expressão de uma idéia-força que deriva do princípio da essencial dignidade da pessoa humana. Precedentes do Supremo Tribunal Federal e da Suprema Corte americana. Positivação desse princípio no plano do direito comparado." RE 477554 AGR/MG - MINAS GERAIS AG.REG. NO RECURSO EXTRAORDINÁRIO Relator(a): Min. CELSO DE MELLO.

23 Há três decisões importantes no campo do Direito de Família, seguindo esta linha de raciocínio. Apresentam-se os trechos importantes dessas decisões com as respectivas indicações do processo nas quais foram prolatadas: a) "Uma sociedade que apresenta como elemento estrutural a monogamia não pode atenuar o dever de fidelidade - que integra o conceito de lealdade - para o fim de inserir no âmbito do Direito de Família relações afetivas paralelas e, por consequência, desleais, sem descurar que o núcleo familiar contemporâneo tem como escopo a busca da realização de seus integrantes, vale dizer, a busca da felicidade (Nancy Andrighi REsp 1157273 / RN. RECURSO ESPECIAL.2009/0189223-0); b) "Deve o juiz, ao analisar as lides de família que apresentam paralelismo afetivo, de acordo com as peculiaridades multifacetadas apresentadas em cada caso, decidir com base na dignidade da pessoa humana, na solidariedade, na afetividade, na busca da felicidade, na liberdade, na igualdade, bem assim, com redobrada atenção ao primado da monogamia, com os pés fincados no princípio da eticidade." (Recurso especial não provido. Massami Uyeda. REsp 1107192 / PR RECURSO ESPECIAL 2008/0283243-0) e c) "Processo civil. Direito da Criança e do Adolescente. Conflito positivo de competência. Ação de guarda de menor ajuizada perante o Juízo de Direito da Vara da Infância e Juventude de Joinville-SC, suscitante. Pedido de providências deduzido pelo Conselho Tutelar perante o Juízo de Direito da Vara da Infância e Juventude de Cachoeira Paulista-SP, suscitado. Pedido de guarda provisória deferido. Doutrina jurídica da proteção integral. Melhor interesse da criança. Princípio da dignidade da pessoa humana, da solidariedade e da busca da felicidade. Competência do Juízo suscitante". (NANCY ANDRIGHI (1118). CC 108442 / SC. CONFLITO DE COMPETENCIA. 2009/0194206-4).

24 Conforme entrevista publicada pelo Jornal Estadão. Disponível em: http://www.estadao.com.br/noticias/nacional,ccj-do-senado-aprova-a-pec-da-felicidade,637879,0.htm Acesso em 14.Set.2012.

25 Informação disponível em: http://www.gazetadopovo.com.br/vidapublica/justica-direito/conteudo. phtml?id=1252973. Acesso em: 16.Set.2012.

26 Disponível em: <http://www.un.org/News/Press/docs//2011/ga11116.doc.htm> Acesso em 14.Set.2012.

REFERÊNCIAS

BENTHAM, Jeremy. Uma introdução aos princípios da moral e da legislação. Os pensadores. Trad. Luiz João Baraúna. São Paulo: Abril Cultural, 1984.

FRANCO FILHO, Odilon de Melo. A civilização do mal estar pela não-felicidade. Revista brasileira de psicanálise Vol. 43, n², 183-192, 2009.

FRANKLIN, Samuel. The psychology of happiness. Cambridge University Press, New York, 2010.

FREUD, Sigmund. O mal-estar na civilização. Sigmund Freud, Obras completas, vol. 18, Trad. Paulo César de Souza. São Paulo: Editora Companhia das Letras, 2010.

GRAHAM, Carol. Happiness around the world: the paradox of happy peasants and miserable millionaires. New York: Oxford University Press, 2009.

GUSTIN, Miracy. Das necessidades humanas aos direitos: ensaio de sociologia e filosofia do direito. Belo Horizonte: Del Rey, 2009.

HALL, Stuart. A identidade cultural na pós-modernidade. Rio de Janeiro: DP\&A Editora, 2011.

HEIDT, Jonathan. The happiness hypothesis - finding modern truth in Ancient Wisdom. Boston: Basic Books, 2005.

INGLEHART, Ronald. e LINGEMANN, Hans-Dieter. Genes, culture, democracy and happiness. 165-183, 2002 disponível em: www2000.wzb.eu/alt/iw/pdf/genecult.pdf

LEWONTIN, Richard, ROSE, Steve. \& KAMIN, Leon. Not in our genes: biology, ideology and human nature. New York: Pantheon, 1984. 
LYKKEN, David.; TELLEGEN, Auke. Happiness is a stochastic phenomenon. Psychological Science. Vol. 7, 1996, 186-189.

KANT, Immanuel. Fundamentação da metafísica dos costumes e outros escritos. Trad. Leopoldo Holzbach. São Paulo: Martin Claret, 2011.

KIRCHOF, Edgard Roberto. Estética e biossemiótica. Porto Alegre: EDIPUCRS, 2008.

MCMAHON, Darrin. Felicidade: uma história. São Paulo: Editora Globo, 2006.

MINOIS, Georges. A idade de outro. História da busca da felicidade. São Paulo: Editora UNESP, 2011.

MORAES, Maria Celina. Na medida da pessoa humana. Estudos de direito civil-constitucional. Rio de Janeiro: Renovar, 2010.

PERLINGIERI, Pietro. La personalità umana nell'ordinamento giuridico. Napoli: Edizione Scientifica Italiana, 1972.

Perfis de direito civil. Rio de Janeiro: Renovar, 2007.

PINKER, Steve. Why nature \& nurture don't go away? Deadelus. 2004, p.5-17.

ROGERS, Alan. Does biology constrain culture? American Anthropologist. Vol. 98, n 4, 1988, p. 819831.

SAHLINS, Marshall. 1976. The use and abuse of biology: an anthropological critique of sociobiology. Ann Arbor: University of Michigan Press, 1976.

SARTRE, Jean Paul. O ser e o nada. Ensaio da ontologia fenomenológica. São Paulo: Vozes, 2009.

$\mathrm{SCHOCH}$, Richard. A história da (in)felicidade. Três mil anos de busca por uma vida melhor. Tradução: Elena Gaidano. Rio de Janeiro: Best Seller, 2011.

SEN, Amartya. A idéia de justiça. São Paulo: Companhia das Letras, 2011.

SHERMER, Michael. Por que as pessoas acreditam em coisas estranhas. Trad. Luis Reyes Gil, São Paulo: JSN editora Ltda., 2011.

SZANIAWSKI, Elimar. Direitos de personalidade e sua tutela. São Paulo: RT, 1993.

TEPEDINO, Gustavo. Temas de direito civil. Vol. 1. Rio de Janeiro: Renovar, 2001.

VEENHOVEN, Ruut. Medidas de la Felicidad Nacional Bruta. Intervención Psicosocial. Revista sobre Igualdad y Calidad de Vida. Vol. 18 n. ${ }^{0} 3$, 2009, p.279-299. Disponível em: <http://www2.eur.nl/fsw/ research/veenhoven/Pub2000s/2009j-fulls.pdf>

WAGNER, Roy. A invenção da cultura. São Paulo: Cosacnaify, 2010.

WILSON, Edward . Sociobiology. Cambridge: Harvard University Press, 1975. 